\title{
FAKTOR-FAKTOR YANG BERHUBUNGAN DENGAN KESESUAIAN PELAKSANAAN STANDAR PELAYANAN KEFARMASIAN DI APOTEK WILAYAH DENPASAR TAHUN 2017
}

\author{
RELATED FACTORS WITH THE FITNESS APPLICATION OF IMPLEMENTATION OF \\ PHARMACEUTICAL SERVICES IN DENPASAR REGION IN 2017
}

\author{
NI PUTU WINTARIANI ${ }^{\bullet}$, DEWA AYU PUTU SATRYA DEWI ${ }^{1}$, NI PUTU DEWI AGUSTINI ${ }^{2}$ \\ ${ }^{1}$ Program Studi Farmasi Klinis, Institut Ilmu Kesehatan Medika Persada Bali \\ ${ }^{2}$ Program Studi DIII Farmasi, Akademi Farmasi Saraswati Denpasar
}

\begin{abstract}
Abstrak: Peningkatan pelayanan kesehatan yang berkualitas merupakan hal yang harus dilakukan dan menjadi perhatian pemerintah saat ini, karena pelayanan kesehatan yang baik akan mampu meningkatkan derajat kesehatan dan kualitas hidup masyarakat yang lebih baik. Salah satu tempat pelayanan kesehatan (kefarmasian) adalah apotek, apotek yang baik adalah apotek yang mampu memberikan pelayanan kesehatan (farmasi) yang optimal. Untuk Mengetahui faktor-faktor yang berhubungan tentang kesesuaian pelaksanaan standar pelayanan kefarmasian berdasarkan Peraturan Menteri Kesehatan No 73 tahun 2016 di apotek wilayah Denpasar tahun 2017. Uji multivariate yang digunakan adalah uji binary logistic. Dari hasil uji multivariat didapatkan hasil kehadiran APA (Apoteker Pengelola Apotek) di apotek $0.000(<0.005)$ dan Status Kepemilikan Apotek 0,004 (<0.005), sehingga dapat disimpulkan kehadiran APA di apotek dan Status kepemilikan apotek berhubungan dengan pelaksanaan standar pelayanan kefarmasian di apotek. Sedangkan omset dengan nilai $0.039 \quad(<0.005)$ tidak memiliki hubungan dengan standar pelaksanaan pelayanan kefarmasian di apotek.
\end{abstract}

Kata kunci : Standar pelayanan kefarmasian apotek, Apoteker

\begin{abstract}
Improving quality health services is something that must be done and the attention of the government at this time; because good health services will be able to improve the health status and quality of life for better society. One place of health services (pharmaceutical) is a pharmacy; a good pharmacy is a pharmacy that is able to provide optimal health (pharmacy) services. To know the related factors about suitability of pharmacy service standard implementation based on Regulation of Minister of Health No. 73 year 2016 at apothecary of Denpasar area 2017. Multivariate test used is binary logistic test. From multivariate test result, the result of APA presence at pharmacy $0.000(<0.005)$ and Pharmacy Ownership Status 0.004 $(<0.005)$, so it can be concluded the presence of APA in pharmacy and pharmacy ownership status related to pharmacy service standard implementation in pharmacy. While the turnover with the value $0.039(<0.005)$ has no relationship with the standard pharmacy service implementation in the pharmacy.
\end{abstract}

Keywords: Pharmaceutical service standard, Pharmacist

\section{PENDAHULUAN}

Peningkatan pelayanan kesehatan yang berkualitas merupakan hal yang harus dilakukan dan menjadi perhatian pemerintah saat ini, karena pelayanan kesehatan yang baik akan mampu meningkatkan derajat kesehatan dan kualitas hidup masyarakat yang lebih baik. Agar tercapai tujuan pembangunan kesehatan itu, diperlukan upaya kesehatan yang menyeluruh dan terpadu (Siregar dan Amalia, 2004).

Salah satu tempat pelayanan kesehatan (kefarmasian) adalah apotek, apotek yang baik adalah apotek yang mampu memberikan pelayanan kesehatan (farmasi) yang optimal. Karena pelayanan apotek yang optimal dapat memberikan hasil yaitu derajat kesehatan masyarakat semakin meningkat. Maka dari itu supaya didapatkan apotek yang optimal dalam melakukan pelayanan kesehatan, apotek perlu menerapkan sistem standar pelayanan kefarmasian yang sudah ditetapkan oleh PMK (Peraturan Menteri Kesehatan No. 73 2016). Jika suatu apotek tidak menggunakan standar pelayanan farmasi dalam menjalankan apotek maka tidak akan tercapai derajat kesehatan yang optimal bagi masyarakat (Hartini dan Sulasmono, 2006).

Pekerjaan Kefarmasian seperti disebutkan dalam Peraturan Pemerintah Nomor 51 Tahun 2009 tentang Pekerjaan Kefarmasian adalah

\footnotetext{
•email korespondensi: putuwinta@gmail.com
} 
pembuatan termasuk pengendalian mutu Sediaan Farmasi, pengamanan, pengadaan, penyimpanan dan pendistribusian atau penyaluran Obat, pengelolaan Obat, pelayanan Obat atas Resep dokter, pelayanan informasi Obat, serta pengembangan Obat, bahan Obat dan Obat tradisional. Kegiatan pelayanan/pekerjaan kefarmasian yang semula hanya berfokus pada pengelolaan obat sebagai komoditi mengalami pergeseran orientasi menjadi pelayanan yang komprehensif yang bertujuan untuk meningkatkan kualitas hidup pasien (pharmaceutical care). Konsekuensi perubahan orientasi tersebut, apoteker dituntut pengetahuan, keterampilan, dan perilaku agar dapat melaksanakan interaksi langsung dengan pasien. Bentuk interaksi tersebut antara lain adalah pemberian informasi Obat dan konseling kepada pasien yang membutuhkan (Permenkes, 2009).

Sampai saat ini masih diragukan seberapa jauh penerapan dari standar pelayanan kefarmasian ini dilakukan di tiap-tiap apotek khususnya di wilayah Denpasar tahun 2017. Dengan beberapa faktor yang dijabarkan tadi, peneliti akan menghubungan faktor-faktor dengan penerapan standar pelayanan kefarmasian, maka penelitian ini harus dilakukan untuk mengetahui seberapa jauh diterapkannya standar ini.

Penelitian dilakukan di Kota Medan tentang Penerapan Standar Pelayanan Kefarmasian di apotek tahun 2008. Penelitian dilakukan dengan metode deskriptif dengan model penelitian survey dan bersifat cross-sectional. Data dikumpulkan dari 68 responden melalui pengisian angket, metode pengambilan sampel adalah stratifikasi sampling. Berdasarkan penelitian tersebut, diketahui bahwa rata-rata skor penilaian pelayanan kefarmasian di apotek Kota Medan tahun 2008 adalah $47,63 \%$ yang termasuk dalam kategori kurang. Diketahui berdasarkan faktor kepemilikan apotek, sebesar 67,65\% apotek milik PMA (Pemilik Modal Apotek) dan dari jumlah tersebut apoteker yang tidak hadir di apotek setiap hari sebanyak 52,94\%. Persentase tertinggi kehadiran apoteker dengan status kepemilikan apotek milik APA yaitu sebesar 78,57\%. Sedangkan persentase kehadiran apotek dihubungkan dengan status APA (pekerjaan lain APA), persentase kehadiran paling tinggi adalah APA dengan pekerjaan lain-lain (Ginting, 2009). Berdasarkan keterangan diatas, peneliti tertarik untuk melakukan penelitian mengenai Faktor-Faktor yang Mempengaruhi Kesesuaian Pelaksanaan Standar Pelayanan Kefarmasian Di Apotek Wilayah Denpasar Tahun 2017.

\section{METODE PENELITIAN}

Penelitian ini dilakukan dengan desain survey cross sectional. Penelitian menggunakan kuesioner sebagai alat pengumpulan data. Teknik sampling yang digunakan adalah purposive sampling untuk mengetahui faktor-faktor yang berhubungan dengan kesesuaian pelaksanaan standar pelayanan kefarmasian di apotek wilayah Denpasar tahun 2017. Lokasi penelitian dilakukan di wilayah kota Denpasar dengan waktu penelitian selama 6 bulan dari bulan Maret 2017 sampai dengan September 2017.

Penelitian ini bermaksud untuk mencari faktor-faktor yang berhubungan dengan kesesuaian pelaksanaan standar pelayanan kefarmasian di apotek wilayah Denpasar tahun 2017. Adapun faktor yang akan diteliti antara lain kepemilikan apotek, omset apotek, kehadiran apotek. Penelitian ini menggunakan instrument berupa kuesioner. Kuesioner terdiri dari 2 bagian. Bagian 1 meliputi karakteristik subjek penelitian yaitu apoteker, antara lain Umur APA, Jenis Kelamin APA,lama menjadi APA, Status Kepemilikan apotek, kehadiran APA di apotek dan Omset Apotek. Bagian 2 meliputi pertanyaan dari peneliti untuk apoteker sebagai koresponden mengenai standar pelayanan kefarmasian, dengan nilai 1 untuk jawaban dilakukan/ punya dan 0 untuk (tidak dilakukan/ tidak punya). Analisis data menggunakan uji multivariate binary logistic untuk melihat hubungan masing-masing variabel dan seberapa besar pengaruh serta mengkontrol variabel compounding. Antara lain status kepemilikan apotek, omset apotek, kehadiran apoteker.

\section{HASIL DAN PEMBAHASAN}

1) Uji Normalitas

Sebelum dilakukan uji multivariat, dilakukan uji normalitas Hasil uji normalitas didapatkan hasil nilai $\mathrm{p}<0.05$, itu artinya data tidak terdistribusi normal, sehingga pengujian dilakukan dengan menggunakan non-parametik tes. Uji normalitas dapat dilihat pada tabel berikut ini:

Tabel 1. Uji Normalitas

\begin{tabular}{|c|c|}
\hline $\begin{array}{c}\text { Faktor yang dilakukan uji } \\
\text { normalitas }\end{array}$ & $p$ \\
\hline $\begin{array}{l}\text { Standar pelaksanaan pelayanan } \\
\text { kefarmasian }\end{array}$ & 0.001 \\
\hline Kehadiran APA & 0.001 \\
\hline Omset Apotek & 0.001 \\
\hline Status Kepemilikan Apotek & 0.001 \\
\hline
\end{tabular}


2) Karakteristik Subyek Penelitian

\section{Tabel 2. Karakteristik Subyek Penelitian}

\begin{tabular}{|c|c|c|c|}
\hline No & $\begin{array}{c}\text { Karakteristik } \\
\text { Subjek Penelitian }\end{array}$ & Jumlah & Persentase \\
\hline \multirow[t]{4}{*}{1} & Umur APA : & & \\
\hline & 26-35 tahun & 59 & $86,8 \%$ \\
\hline & 36-50 tahun & 5 & $5,8 \%$ \\
\hline & $>50$ tahun & 5 & $7,3 \%$ \\
\hline \multirow[t]{3}{*}{2} & Jenis kelamin : & & \\
\hline & Perempuan & 44 & $63,2 \%$ \\
\hline & Laki-laki & 25 & $36,7 \%$ \\
\hline \multirow[t]{5}{*}{3} & Lama menjadi APA & & \\
\hline & $:$ & 62 & $91,2 \%$ \\
\hline & $\leq 10$ tahun & 3 & $2,9 \%$ \\
\hline & $11-20$ tahun & 6 & $5,9 \%$ \\
\hline & 21-30 tahun & & \\
\hline \multirow[t]{3}{*}{4} & $\begin{array}{l}\text { Status kepemilikan } \\
\text { apotek: }\end{array}$ & 11 & $16,2 \%$ \\
\hline & Milik APA & 58 & $83,8 \%$ \\
\hline & Milik PSA & & \\
\hline \multirow[t]{9}{*}{5} & Kehadiran : & & \\
\hline & Selama apotek buka & 5 & $7.2 \%$ \\
\hline & (1) & 11 & $15.9 \%$ \\
\hline & Setiap hari pada jam & 2 & $2.9 \%$ \\
\hline & tertentu (2) & 34 & $49.3 \%$ \\
\hline & 1 kali seminggu & 17 & $26,6 \%$ \\
\hline & 2-3 kali seminggu & & \\
\hline & & & \\
\hline & 1 kali sebulan (4) & & \\
\hline \multirow[t]{12}{*}{6} & Rata-rata omset per & & \\
\hline & hari : & 11 & $15.9 \%$ \\
\hline & $\leq \mathrm{Rp} 1.000 .000$ & 11 & $15.9 \%$ \\
\hline & $>$ Rp1.000.000- & 6 & $8,7 \%$ \\
\hline & Rp2.000.000 & 14 & $20,3 \%$ \\
\hline & $>$ Rp2.000.000- & 20 & $29.0 \%$ \\
\hline & Rp3.000.000 & 7 & $10.1 \%$ \\
\hline & $>$ Rp3.000.000- & & \\
\hline & Rp5.000.000 & & \\
\hline & $>$ Rp5.000.000- & & \\
\hline & Rp10.000.000 & & \\
\hline & $>\mathrm{Rp} 10.000 .000$ & & \\
\hline
\end{tabular}

Distribusi terhadap karakteristik umur APA, dimana kelompok APA yang berumur 26-35 tahun $(60,3 \%)$ lebih tinggi dibandingkan kelompok APA yang berumur 36-50 tahun $(5,8 \%)$ dan $>50$ tahun (7,3\%). Berdasarkan distribusi jenis kelamin APA, kelompok APA yang berjenis kelamin perempuan lebih tinggi $(63,2 \%)$ dibandingkan kelompok APA yang berjenis kelamin laki-laki $(36,7 \%)$.

Untuk karakteristik lama berprofesi sebagai apoteker paling lama adalah 30 tahun dan paling sedikit adalah 1 tahun. Jumlah APA yang paling tinggi telah lama berprofesi sebagai apoteker adalah $<10$ tahun yaitu sebanyak 62 APA $(91,2 \%)$. Kategori lama berprofesi sebagai apoteker 11-20 tahun sebanyak 3 APA $(2,9 \%)$ dan kategori lama menjadi APA 21-30 tahun sebanyak 6 APA (5,9\%). karakteristik subjek berdasarkan status kepemilikan apotek diketahui distribusi apotek yang dimiliki sendiri oleh APA lebih kecil yaitu $16,2 \%$ (11 apotek) dibandingkan dengan apotek yang diberikan modal oleh PSA 83,8\% (58 apotek).

Omset per hari yang didapatkan apotek wilayah Denpasar tahun 2017 paling tinggi yaitu $>$ Rp 10.000.000 sebanyak 7 apotek (10.1\%), > Rp 5.000.000- Rp 10.000.000 sebanyak 20 apotek (29.0\%), dan >Rp3.000.000-5.000.000 sebanyak 14 apotek (20,3\%).Sedangkan omset paling rendah yaitu $\leq$ Rp1.000.000 sebanyak 11 apotek (15.9\%), $>$ Rp1.000.000-Rp2.000.000 sebanyak 11 apotek (15.9\%), dan >Rp2.000.000-Rp3.000.000 sebanyak 6 apotek $(8,7 \%)$.

Karakteristik kehadiran APA di apotek Kota Denpasar tahun 2017 secara keseluruhan menunjukkan masih banyak APA yang kehadirannya belum sesuai dengan standar. Kehadiran yang dianggap sesuai dengan standar pelayanan kefarmasian adalah Kehadiran yang dianggap sesuai dengan standar pelayanan kefarmasian adalah kehadiran 1 dan 2 yaitu APA hadir selama apotek buka dan setiap hari pada jam tertentu untuk melakukan pelayanan kefarmasian. Distribusi kehadiran 1 (selama apotek buka) sebanyak 5 orang $(7,2 \% \%)$ dan 2 (setiap hari pada jam tertentu) sebanyak 11 orang $(15,9 \%)$. Kemudian kehadiran 3 yaitu 1 kali seminggu sebanyak 2 orang (2.9\%), 2-3 kali seminggu sebanyak 34 orang (49.3\%) dan kehadiran 4 yaitu 1 kali sebulan sebanyak 17 orang $(24,6 \%)$. Hasil yang didapatkan kehadiran 1 dan 2 masih sangat rendah masih belum memenuhi standar sesuai dengan standar pelayanan kefarmasian yang baik.

Penelitian lain yang dilakukan pada apotek di Kota Denpasar dan beberapa daerah di Badung tahun 2011 menunjukkan bahwa kesadaran apoteker masih sangat rendah untuk hadir memberikan pelayanan kefarmasian di apotek. Dari total 111 apotek di wilayah Denpasar Utara, Denpasar Timur, Denpasar Selatan, Denpasar Barat, Kuta Utara, dan Kuta Selatan, hanya 26,64\% yang terdapat tenaga ahli apoteker di apotek pada saat dilakukannya survey (Gunawan,. dkk, 2011).

Kehadiran APA berpengaruh terhadap kualitas pelayanan kefarmasian di apotek. Survey yang telah dilakukan pada 68 apotek di Kota Denpasar diketahui bahwa apotek yang kualitas pelayanan kefarmasian buruk masih cukup tinggi yaitu 51,4\% (2-3 kali seminggu) dan 26,6\% 
(sebulan sekali). Kualitas pelayanan kefarmasian di daerah lain seperti Kota Medan dan Nusa Tenggara barat tidak jauh berbeda dengan kondisi pelayanan kefarmasian di Kota Denpasar, dimana kualitas pelayanan kefarmasiannya masih kurang baik dan masih perlu terus adanya peningkatan kualitas pelayanan. Rata-rata skor pelaksanaan pelayanan kefarmasian di Apotek di Kota Medan 47,63 yang termasuk dalam kategori pelayanan kefarmasian yang kurang baik. Pada apotek di Kota Medan, persentase terbesar yang melakukan pelayanan kefarmasian langsung dengan pasien adalah asisten apoteker sebesar $83,82 \%$, apoteker dan tenaga non farmasi $16,18 \%$. Hal ini disebabkan karena APA yang jarang hadir dan memberikan pelayanan di apotek, sehingga pelayanan kefarmasian lebih banyak dilakukan oleh asisten apoteker (Ginting, 2009).

\section{3) Analisis Multivariat}

Hasil analisis multivariate menyatakan bahwa faktor-faktor yang berhubungan dengan keterlaksanaan standar pelayanan kefarmasian anatara lain umur memiliki hubungan yang tidak signifikan $(\mathrm{p}=0,96)$ dan hanya memberikan pengaruh sebesar 0,96 kali $(\mathrm{OR}=0,96)$, jenis kelamin APA dengan nilai $(\mathrm{p}=238)$ yang artinya memliki hubungan tidak signifikan dan hanya memberikan pengaruh sebesar 0,45 kali $(\mathrm{OR}=$ 0,45). Nilai signifikasi dari lama APA sebagai apoteker adalah $(\mathrm{p}=0,41)$ memiliki hubungan yang tidak signifikan dengan memiliki pengaruh sebesar 0,96 kali $(\mathrm{OR}=0,96)$. Kemudian status kepemilikan apotek memiliki hubungan yang tidak signifikan yaitu $(\mathrm{p}=0,99)$, dan sama sekali tidak memiliki pengaruh $(\mathrm{OR}=0)$.

Hasil analisis untuk omset apotek memiliki hubungan yang tidak signifikan yaitu $(\mathrm{p}=0,68)$ dan pengaruh 0,93 kali $(\mathrm{OR}=0,93)$ dan kehadiran APA di apotek memiliki hubungan yang signifikan karena memiliki nilai $(\mathrm{p}=0,001)$ dan memiliki kekuatan pengaruh paling besar yaitu 2 , 415 kali $(\mathrm{OR}=2,415)$.sehingga dapat disimpulkan kehadiran APA berhubungan dengan pelaksanaan standar pelayanan kefarmasian di apotek.

Hasil penelitian yang digunakan untuk memperkuat adalah diketahui bahwa faktor kehadiran APA, kepemilikan apotek, motivasi APA dan status APA memiliki pengaruh terhadap kualitas pelayanan kefarmasian di apotek Kota Denpasar. Semakin baik tingkat kehadiran APA maka peluang kualitas pelayanan kefarmasiannya juga semakin baik. Hasil ini sama dengan hasil penelitian terdahulu tahun 2016 oleh Noviannita yaitu semakin tinggi tingkat kehadiran APA di apotek peluang apotek untuk dapat memberikan pelayanan kefarmasian yang baik semakin meningkat. Apotek yang dimiliki langsung oleh APA memberikan peluang apotek untuk dapat memberikan pelayanan kefarmasian yang lebih baik dibandingkan dengan apotek yang pemiliknya bukan APA atau dimiliki oleh PMA (Novianita, 2016). Analisis multivariat dapat dilihat di tabel multivariat:

\begin{tabular}{clll}
\multicolumn{5}{c}{ Tabel 3. Tabel Multivariat } \\
\hline No & $\begin{array}{c}\text { Faktor-faktor yang } \\
\text { berhubungan dengan } \\
\text { standar keterlaksanaan } \\
\text { pelayanan kefarmasian }\end{array}$ & OR & $\begin{array}{c}\boldsymbol{P}(>\mathbf{0 . 0 5}) \\
\text { tidak ada } \\
\text { pengaruh }\end{array}$ \\
\hline $\mathbf{1}$ & Umur APA & 0.96 & 0.96 \\
\hline $\mathbf{2}$ & Jenis kelamin APA & 0.45 & 0.238 \\
\hline $\mathbf{3}$ & $\begin{array}{l}\text { Lama sebagai APA di } \\
\text { apotek }\end{array}$ & 0.96 & 0.41 \\
\hline $\mathbf{4}$ & Status kepemilikan apotek & 0 & 0.99 \\
\hline $\mathbf{5}$ & Kehadiran APA di apotek & 2.415 & 0.001 \\
\hline $\mathbf{6}$ & Omset apotek & 0.93 & 0.68 \\
\hline
\end{tabular}

\section{KESIMPULAN}

1. Pelaksanaan pelayanan kefarmasian di apotek wilayah Denpasar tahun 2017 dengan peraturan Menteri Kesehatan No 73 Tahun 2016 tentang standar pelayanan kefarmasian di apotek yaitu tidak sesuai dengan standar $(60,9 \%)$ dan yang sesuai dengan standar $(39,1 \%)$.

2. Faktor-faktor yang berhubungan dengan kesesuaian pelaksanaan pelayanan kefarmasian di apotek wilayah Denpasar tahun 2017 sesuai dengan peraturan Menteri Kesehatan No 73 Tahun 2016 tentang standar pelayanan kefarmasian di apotek adalah kehadiran APA di apotek, memiliki hubungan yang signifikan dengan nilai $(\mathrm{p}=0.001)$ dan nilai $(\mathrm{OR}=2.415)$.

\section{UCAPAN TERIMAKASIH}

Puji syukur kehadapan tuhan YME, penulis dapat menyelesaikan penyusunan jurnal yang berjudul "Faktor-Faktor yang Berhubungan dengan Kesesuaian Pelaksanaan Standar Pelayanan Kefarmasian di Apotek Wilayah Denpasar Tahun 2017'. Penulis menyadari jurnal ini tidak akan selesai tanpa bantuan berbagai pihak. 


\section{DAFTAR PUSTAKA}

Anonim, 2016, Peraturan Menteri Kesehatan Republik Indonesia No. 73 tentang Standar Pelayanan Kefarmasian Di Apotek, Jakarta.

Anonim,2002, Keputusan Menteri Kesehatan Nomor:1332/MENKES/SK/X/2002,

Tentang Ketentuan dan Tata Cara Pemberian Izin Apotek, Jakarta.

Dinas Kesehatan Provinsi Bali. 2014. Profil Kesehatan Provinsi Bali Tahun 2013. Dinas Kesehatan Provinsi Bali.

Dinas Perijinan Kota Denpasar. 2014. Data Permohonan Ijin Apotek. Denpasar. BPPSP dan Pemerintahan Kota Denpasar

Ginting, BR Adelina. 2009. Penerapan Standar Pelayanan Kefarmasian di Apotek di Kota Medan Tahun 2008 (Skripsi). Fakultas Farmasi Universitas Sumatera UtaraMedan.

Gunawan, Rai., dkk. 2011. Tingkat Kehadiran Apoteker Serta Pembelian Obat Keras Tanpa Resep di Apotek. Bali : Jurusan Farmasi Fakultas Matematika dan Ilmu Pengetahuan Alam Universitas Udayana.
Hartini, Y.S, dan Sulasmono, 2006, Apotek : Ulasan Beserta Naskah Peraturan Perundang-undangan Terkait Apotek, Universitas Sanata Dharma, Yogyakarta.

Keputusan Menteri Kesehatan RI. 2004. Standar Pelayanan Kefarmasian Di Apotek.

Kuncahyo, I. 2004. Dilema Apoteker dalam Pelayanan Kefarmasian. Surakarta. http://www.suarapembaruan.com/news/20 04/04/29/Editor/edi04.htm

Departemen Kesehatan RI, Jakarta. Keputusan Menteri Kesehatan RI. (2002). Tentang Ketentuan Dan Tata Cara Pemberian Izin Apotik. Departemen Kesehatan RI, Jakarta.

Novianita, 2016, Pengaruh Apoteker Pengelola Apotek terhadap Kualitas Pelayanan Kefarmasian di Apotek-apotek Kota Denpasar, universitas Udayana, Denpasar

Peraturan Pemerintah RI. (2009). Pekerjaan Kefarmasian. Departemen Kesehatan RI, Jakarta.

Siregar, J.P.C dan Amalia, L. 2004. Farmasi Rumah Sakit Teori dan Penerapan. Jakarta: EGC. Hal. 7, 13-15, 17-19. 